\title{
KECEPATAN LAJU REPRODUKSI VEGETATIF BERBAGAI JENIS BAMBU DI PPKA BODOGOL, TAMAN NASIONAL GUNUNG GEDE PANGRANGO
}

\author{
Syifa Eka Sulistyowati ${ }^{1}$, Dita Ervianti ${ }^{1}$, Maulidia A. R. Marmy ${ }^{2}$, Rani F. Andriani ${ }^{1}$, dan Risna \\ Fauziah ${ }^{2}$ \\ ${ }^{1}$ Prodi Biologi FMIPA Universitas Negeri Jakarta, Indonesia. ${ }^{2}$ Prodi Pendidikan Biologi FMIPA Universitas \\ Negeri Jakarta, Indonesia.
}

Email: chypa_cupu@yahoo.com

\begin{abstract}
Bamboo spread naturally in tropical and subtropical regions of all continents except Europe, found at altitudes of up to 4000 meters above sea level. In the rainy season bamboo will experience growth of stems or bamboo shoot can grow $70 \%$ maximum height and diameter. The purpose of this research to determine the rate of growth of bamboo in PPKA Bodogol, Gunung Gede Pangrango National Park. The result found 8 types of bamboo, there are Schizostachyum bamban, Gigantochloa pseudoarundinacea, Dinochloa scandens, Bambusa vulgaris, Gigantochloa apus, Gigantochloa atter, Gigantochloa hasskarliana, and Gigantochloa sp. The growth rate all of species is $13,49 \mathrm{~cm} /$ day. From some types of bamboo are obtain that the growth is above average and is found on the Schizostachyum bamban, Gigantochloa sp.. The Species has fastest growth is Gigantochloa sp and the longest is Gigantochloa apus.
\end{abstract}

Key words: bamboo, bamboo shoot, Gigantochloa, the rate of growth

\section{PENDAHULUAN}

Bambu tersebar secara alami pada daerah tropis dan subtropis pada semua benua kecuali di Eropa, ditemukan pada ketinggian hingga 4000 meter diatas permukaan laut (Scurlock, Dayton, \& Hames, 2000). Secara global, kurang lebih terdapat 40 ribu hektar hutan bambu (Lobovikov, Ball, Guardia, \& Russo, 2007), yang merupakan 1\% dari total keseluruhan area hutan di dunia. Hingga saat ini bamboo terdiri dari 1250 spesies dalam 90 genus (Dura \& Hiura, 2006), sedangkan di Pulau Jawa sendiri terdapat lebih dari 25 genus bambu (Widjaja, 2001).

Bambu terdiri dari buluh atau batang yang ada di permukaan tanah, buluhnya bercabang-cabang dengan memiliki pelepah (sheath) dan daun, dan pada sistem bawah tanahnya terdapat rhizome yang solid ataupun bolong (Lobovikov, Schoene, \& Yping, 2012). Bambu memiliki dua bentuk rhizome utama, yaitu: simpodial dan monopodial, klasifikasi tersebut didasarkan pada bentuk dan perilaku (behavior) dari spesies bambu tersebut. Pada rhizome terdapat kuncup atau tunas yang nantinya akan berkembang menjadi rebung, selain dari rhizome rebung juga dapat muncul dari pangkal buluh yang sudah tua (Widjaja, 2001). Diameter rebung merupakan diameter inisiasi bambu yang akan seterusnya menjadi diameter bambu tersebut selama masa hidupnya. Yang akan berubah hanyalah panjang dari internodusnya. Pertumbuhan terbaik bambu terjadi di lingkungan yang lembab, beriklim tropis, mendapat pencahayaan matahari penuh, lokasi yang datar dengan sistem pengairan yang bagus, dan kaya 
akan nutrisi tanah (Le, 2009). Pada musim hujan batang atau rebung bambu akan memulai pertumbuhannya dan dapat berkembang hingga 70\% tinggi dan diameter maksimumnya. Pada kondisi optimum rebung akan tumbuh dan mengalami pemanjangan hingga $90-120 \mathrm{~cm}$ perhari dan mencapai tinggi maksimumnya dalam waktu dua sampai empat bulan (Dura \& Hiura, 2006).

Tujuan dari penelitian ini yaitu untuk mengetahui jenis-jenis bambu yang ada di PPKA Bodogol dan mengetahui laju pertumbuhan dari masing-masing jenis bambu tersebut.

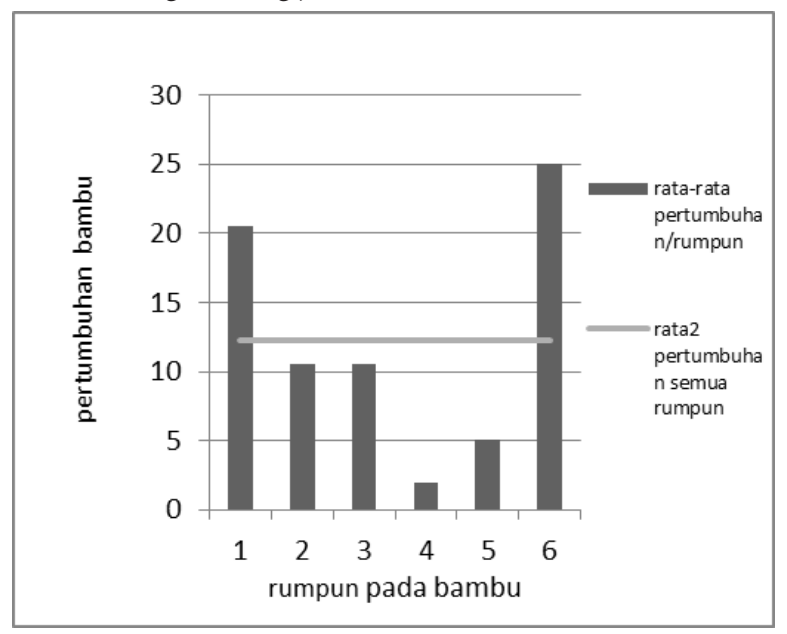

\section{Gambar 1. Rata - rata pertumbuhan bambu tiap rumpun}

\section{METODE PENELITIAN}

Penelitian dilaksanakan di Pusat Pendidikan Konservasi Alam Bodogol, Sukabumi-Jawa Barat. Penelitian dilakukan selama empat hari pada tanggal 27 -30 Juni 2013. Alat yang digunakan dalam penelitian ini adalah GPS, meteran gulung, meteran jahit, $\mathrm{pH}$ soil tester, penggaris, jangka sorong, inklinometer, kamera, alat tulis serta tabulasi data.

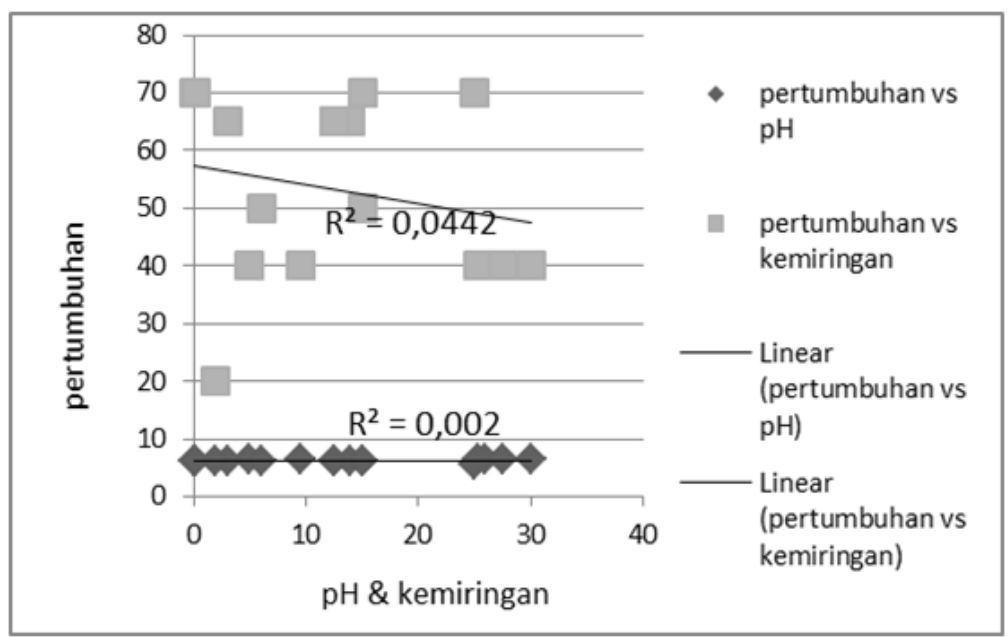

Gambar 2. Pengaruh pertumbuhan dengan pH dan kemiringan

Metode penelitian yang digunakan adalah metode deskriptif dengan teknik survei dan pengambilan data dilakukan dengan teknik purposive sampling. Pada penelitian ini menggunakan 3 jalur yaitu jalur Longtrack, Cikaweni 
dan Rasamala. Pada setiap jalur yang dilalui di catat jenis - jenis bambu dan mengelompokkan rumpun yang memiliki rebung, kemudian rebung dihitung jumlahnya kemudian masing - masing diukur tingginya menggunakan meteran jahit dan diameternya menggunakan jangka sorong, selanjutnya mengukur $\mathrm{pH}$ dan kemiringan rumpun bambu. Untuk melakuakan uji statistik yakni uji korelasi dan regresi.

\section{HASIL}

Hasil survei di PPKA Bodogol Taman Nasional Gunung Gede Pangrango ditemukan 8 jenis Bambu yaitu, Schizostachyum bamban, Gigantochloa pseudoarundinacea, Dinochloa scandens, Bambusa vulgaris, Gigantochloa apus, Gigantochloa atter, Gigantochloa hasskarliana, dan Gigantochloa sp.. Bambusa vulgaris ditemukan di sepanjang jalur Rasamala dengan persebaran yang menyebar, Schyzotaschyum bamban di temukan di jalur longtrack dengan persebaran menggerombol, Gigantochloa atter ditemukan di jalur longtrack bagian lembah pada daerah ini jenis tersebut sangat mendominasi walau sesekali ditemukan Gigantochloa pseudoarundinacea disana tetapi setelah mencapai bukit Gigantochloa pseudoarundinacea ditemukan paling mendominasi dengan persebarannya yang menyebar. Gigantochloa sp. ditemukan mendominasi di jalur cikaweni.

\section{PEMBAHASAN}

Daerah persebaran antara satu jenis bambu dengan jenis bambu lainnya jarang terjadi tumpang tindih. Hal ini bertujuan untuk pengaturan dari setiap jenis agar tidak terjadi persaingan dalam memperoleh nutrisi dari tanah. Dari ke-8 spesies tersebut yang ditemukan sedang bertunas atau memiliki rebung yang keluar dari dasar tanah hanyalah Schizostachyum bamban (rumpun 1-3), Gigantochloa apus (rumpun 4 dan 5) dan Gigantochloa sp. (rumpun 6) dengan jumlah keseluruhan rebung sebanyak 17 buah. Rata - rata pertumbuhan rebung yaitu 13, 49 $\mathrm{cm} /$ hari. Laju pertumbuhan panjang rebung dari keenam rumpun bambu di PPKA Bodogol menunjukkan hasil yang berbeda-beda. Pertumbuhan yang diatas rata - rata ditemukan pada Schizostachyum bamban rumpun 1 dan Gigantochloa sp. rumpun 6. Menurut Mohmod (1993), faktor genetik memang memegang peranan penting terhadap laju pertumbuhan, spesies yang berbeda memiliki laju pertumbuhan yang berbeda pula disamping faktor lingkungan seperti cahaya, nutrisi tanah, dan $\mathrm{pH}$ tanah. $\mathrm{pH}$ tanah pada rumpun 1 adalah 6,4 sedangkan pada rumpun 6 adalah 5,5. Hal ini sesuai dengan pendapat Mohmod (1993) bahwa bambu dapat hidup pada rentang pH 5,0 sampai 6,5.

Pada grafik 2 dijelaskan pengruh pertumbuhan dengan $\mathrm{pH}$ dan kemiringan. Hasil analisa menunjukkan bahwa rebung bambu yang berada pada lokasi miring laju pertumbuhannya lebih lambat dibandingkan dengan rebung bambu yang berada pada lokasi datar. Hal ini dimungkinan terjadi karena pada lokasi miring lebih berpeluang terjadinya pencucian zat hara oleh air hujan, zat hara diperlukan rebung bambu dan hal tersebut berkaitan dengan proses asimilasi karbon dalam mendukung pertumbuhannya yang cepat (Xu et al., 2011). Hasil asimilasi tersebut selanjutnya akan di transfer menuju rebung untuk melakukan proses pemanjangan (Liese, 2009). Hal ini sesuai dengan analisa, Gigantochloa apus mengalami laju pertumbuhan rebung paling lambat karena berada pada lokasi yang paling miring (700) dibanding kemiringan seluruh rumpun bambu yang didata.

Dari pengujian secara statistik dengan menggunakan uji regresi dan korelasi, dapat dinyatakan hubungan antara pertumbuhan vegetatif bambu dengan $\mathrm{pH}$ memiliki regresi yang lemah yakni 0 , 29. Untuk mendapatkan regresi yang baik maka harus dilakukan pengambilan data lingkungan seperti kelembaban tanah dan nutrisi tanah yang sangat menunjuang laju pertumbuhan dari bambu itu sendiri. 


\section{KESIMPULAN}

1. Ditemukan 8 jenis bambu, dengan spesifikasi 1 jenis (Bambusa vulgaris) di jalur Rasamala, 1 jenis (Gigantochloa sp.) di jalur Cikaweni dan 6 jenis (Schizostachyum bamban, Gigantochloa pseudoarundinacea, Dinochloa scandens, Gigantochloa apus, Gigantochloa atter, dan Gigantochloa hasskarliana) di jalur Longtrack.

2. Kecepatan rata-rata vegetatif bambu yang ada di Bodogol 13,44 cm / hari.

3. Jenis bambu yang memiliki pertumbuhan di atas rata - rata yaitu Gigantochloa sp. dan Schizostachyum bamban sedangkan yang terlambat yaitu Gigantochloa apus.

4. Faktor lingkungan meliputi kemiringan dan $\mathrm{pH}$ memiliki pengaruh yang sedikit terhadap pertumbuhan vegetatif bambu.

\section{DAFTAR PUSTAKA}

Dura, D. B., \& Hiura, H. (2006). Expansion characteristics of bamboo stand and sediment disaster in South Western Japan. Pakistan Journal of Biological Sciences, 9(4), 622-631.

Le, T. X. (2009). Study on the growth of white bamboo (Dendrocalamus membranaceus Munro) under different ecological factors. Colorado State University.

Liese, W. (2009). Bamboo as carbon sink-fact or fiction? Journal of Bamboo and Rattan, 8(3/4), 103-114.

Lobovikov, M., Ball, L., Guardia, M., \& Russo, L. (2007). World bamboo resources: a thematic study prepared in the framework of the global forest resources assessment 2005 (Vol. 18). Food \& Agriculture Org.

Lobovikov, M., Schoene, D., \& Yping, L. (2012). Bamboo in climate change and rural livelihoods. Mitigation and Adaptation Strategies for Global Change, 17(3), 261-276.

Mohmod, A. L. (1993). Effects of age and height of three bamboo species on their machining properties. Journal of Tropical Forest Science, 5(4), 528-535.

Scurlock, J. M. O., Dayton, D. C., \& Hames, B. (2000). Bamboo: an overlooked biomass resource? Biomass and Bioenergy, 19(4), 229-244.

Widjaja, E. A. (2001). Identifikasi Jenis-Jenis Bambu di Jawa. Bogor: Pusat Penelitian Dan Pengembangan BiologiLIPI Dan Balai Penelitian Botani, Herbarium Bogoriense.

Xu, Y., Wong, M., Yang, J., Ye, Z., Jiang, P., \& Zheng, S. (2011). Dynamics of carbon accumulation during the fast growth period of bamboo plant. The Botanical Review, 77(3), 287-295. 